\title{
Jargon language Madura in the community coastal in Pamekasan district (A linguistic study)
}

\author{
Ria Kasanova *), \\ Universitas Madura \\ Muhammad Darrin Zuhri, \\ Universitas Madura \\ *) Correspondences author: Jl. Panglegur Km 3 No. 5 Panglegur, Tlanakan, Kab. Pamekasan, Jawa Timur 69317; Indonesia \\ e-mail: kasanovaria@gmail.com
}

\begin{abstract}
In a society there is no uniformity of language, although in a monolingual language society (society uses only one language in all life activities). Thus it is clear that the language is not monolithic, not only in one form, but in various forms. Languages that are still within the scope of the same language system (langue) are called language variants. The phenomenon of language other than can be observed as a phenomenon of system or language structure can be observed as a social phenomenon. As a social phenomenon, the use of language in society is influenced by situational factors. In relation to the above matter in this study the researchers further study it through the title of research 'Jargon Madurese Language In Coastal Communities in Pamekasan District (A Linguistic Review)'.
\end{abstract}

Key Words: Jargon Language, Fisherman, Madura.

Article History: Received: 24/11/2017; Revised: 23/11/2017; Accepted: 29/11/2017; Published: 20/12/2017

How to Cite (MLA $7^{\text {th }}$ ): Kasanova, Ria and Muhammad Darrin Zuhri. "Jargon language Madura in the community coastal in Pamekasan district (A linguistic study)." Hortatori Jurnal Pendidikan Bahasa dan Sastra Indonesia 1.2 (2017): 160-164. Print/Online. Copyrights Holder: Kasanova, Ria and Muhammad Darrin Zuhri. First Publication: Hortatori Jurnal Pendidikan Bahasa dan Sastra Indonesia (2017).

This work is licensed under a Creative Commons Attribution-ShareAlike 4.0 International License.

\section{Pendahuluan}

Sebagaimana kita ketahui, banyak orang yang mendefinisikan tentang bahasa, bergantung dari sudut mana definisi itu dibuat. Salah satunya seperti yang di sepakati kaum struktural, yakni bahasa didefinisikan sebagai sistem tanda arbitrer yang konvensional. Dengan kata lain, bahasa dikatakan bersifat sistematik dan sistemik. Bahasa bersifat sistematik karena mengikuti ketentuan-ketentuan atau kaidahkaidah yang teratur, sedangkan bahasa bersifat sistemik karena bahasa itu sendiri merupakan suatu sistem atau subsistem-subsistem. Misalnya, subsistem fonologi, subsistem morfologi, subsistem sintaksis, subsistem semantic, dan subsistem leksikon Soeparno (2002:1).

Sedangkan Sausure sebagaimana dikutip Soeparno (2002:1) menyatakan tentang bahasa yang merupakan paduan antara dua unsur, yaitu signifie dan signifiant. Signifie adalah unsur bahasa yang berada dibalik tanda yang berupa konsep di dalam benak penutur, atau biasa disebut dengan makna. Sedangkan signifiant adalah unsur bahasa yang merupakan wujud fisik atau yang berupa tanda ujar.

Kenyataannya keragaman bahasa yang sudah pasti disesuaikan dengan situasi dan kebutuhan, akan menimbulkan bermacam-macam manfaat pemakaian bahasa. Menurut Sugono (1997:10) terdapat tiga kriteria yang berkaitan dengan ragam bahasa tertentu, yakni (1) media yang digunakan, (2) latar belakang penutur, dan (3) pokok permasalahan yang dibicarakan. Berdasarkan media yang diguanakan dikenal dengan ragam bahasa lisan dan ragam bahasa tulis. Dari segi penutur ragam bahasa dibedakan menjadi ragam daerah (dialek), ragam bahasa terpelajar, ragan bahasa resmi, dam ragam bahasa tidak resmi. 
Masyarakat nelayan di Pamekasan merupakan suatu kelompok masyarakat yang memiliki variasai bahasa tersendiri dibandingkan dengan masyarakat pada umumnya, dan banyak sekali didalamnya tediri dari kelompok-kelompok sosial yang berbeda-beda, yakni: kelompok tani, pedagang, pelajar, dan sebagainya yang terlibat langsung dengan masyarakat nelayan. Sebagian besar mereka menggunakan bahasa Madura dalam berkomonikasi sehari-hari. Mereka tidak hanya menggunakan satu macam bahasa tetapi juga dapat menggunakan dan memakai variasi bahasa.

Dari sekian variasi bahasa yang ada, peneliti merasa tertarik untuk mengadakan pengkajian lebih dalam tentang bentuk "jargon" bahasa Madura, khususnya dikalangan masyarakat nelayan. Ketertarikan ini dilandasi oleh beberapa alasan, antara lain kenyataan bahwa hingga saat ini di pulau Madura melaut merupakan salah satu mata pencaharian masyarakat Madura, mengingat Madura merupakan daerah kepulauan yang terdapat banyak kekayaan lautnya. Tentunya penggunaan variasi bahasa Madura akan tetap digunakan oleh masyarakat, khususnya ketika mau melaut.

\section{Metode}

Berdasarkan tujuan yang ingin dicapai dalam penelitian ini, metode yang dipergunakan dalam penelitian ini adalah metode deskriptif kualitatif, yaitu menganalisis data yang digambarkan dengan katakata atau kalimat dipisah-pisahkan menurut katagori untuk memperoleh kesimpulan. Bogdan dan Taylor (dalam Moleong, 2003:3) mendefinisikan penelitian kualitatif sebagai prosedur penelitian yang menghasilkan kata-kata tertentu dari orang-orang dan prilaku yang dapat diamati.

Dalam pengumpulan data penelitian ini, ada tiga proses yang akan dilakukan oleh peneliti, yaitu: a. Proses memasuki lokasi penelitian (getting in)

Pada tahap ini, sebagai orang yang tidak dikenal terlebih dahulu melapor dan memperkenalkan diri kepada Kepala Desa, dengan menunjukkan surat izin penelitian. Selanjutnya mengungkapkan maksud dan tujuan peneliti, sekaligus berkenaan dengan minta izin sebagai tanda bahwa peneliti benar-benar melakukan penelitian.

b. Ketika berada dilokasi penelitian (getting a long)

Dalam hal ini peneliti akan membaur dengan situasi tempat yang diteliti, dan melakukan hubungan inpersonal, sehingga terjalin keakraban dengan informan penelitian. Dengan demikian peneliti dapat berusaha melakukan pengamatan, baik langsung maupun tidak langsung, berdiskusi, tukar menukar informasi, sehingga terjadi diskursus.

Hasil diskursus tadi akan ditranskipkan kedalam tulisan ortografi/ ditunjukkan kedalam bahasa Madura dan diklasifikasikan ke dalam golongannya, akhirnya dapat dideskripsikan secara kualitatif.

c. Pengumpulan data (longing the data)

Dalam penelitian ini, peneliti menggunakan teknik pengumpulan data sebagai berikut:

1) Observasi partisipan ialah suatu cara yang digunakan untuk memperoleh data atau informasi melalui panca indra yang dilakukan secara sistematis, guna memahami dan memperhatikan objek yang diamatinya dan apabila observasi (orang yang melakukan observasi) turut ambil bagian atau berada dalam keadaan objek yang diobservasi (disebut observees) Narbuko (2003:72).

2) Interview (wawancara) adalah proses tanya jawab dalam penelitian yang berlangsung secara lisan dalam dua atau lebih bertatap muka mendengarkan secara langsung informasi-informasi atau keterangan-keterangan (Narbuko, 2003:75-76).

3) Dokumentasi yaitu pengumpulan data yang mempelajari dan meyakinkan dokumem-dokumen yang terkait dengan fokus penelitian. Dokumen yang dipergunakan untuk menunjang pemahaman dan penggalian data dalam penelitian ini bisa berupa peta desa, jumlah penduduk, penghasilan penduduk, dan lain sebagainya.

4) Perekaman dan pencatatan setiap ungkapan yang didengar, direkam, dan dicacat.

\section{Hasil dan Diskusi}

Memperhatikan definisi jargon, yaitu wujud variasi bahasa yang pemakainya terbatas pada kelompok-kelompok sosial tertentu. Istilah-istilah yang dipakai sering tidak dimengerti oleh masyarakat umum dam masyarakat di luar kelompoknya. Kelompok pemakai jargon ini biasanya menggunakan istilahistilah khusus namun tidak bersifat rahasia.

1. Rèya nyamana messin lari cong! 
2. Tang jhârmudhi karè sakè' bâri'

3. Messin Jènsèt satèya larang tiyâ?

4. Pajâng pursin rè bâk powa polana la alpo'

5. Mon jhâmpang rèya èangghui pajâng

6. Mon malem, mon ta' nagngghui sukle ta' paddhâng jhoko'en

7. Jiya ker-taker cong, mon ollè ma'lè padhâ ètaker

8. Yâ prao mon terro ta' buruâh èberri' mangghâr

9. Makè ojhân ta' kèra bâcca klambhina jâ'rèng èsabâ' èsanggan

10. Malemma ta' ollè makè nyolo

11. Nyarè bhurâ'ân ta' ollè apa

12. Pola lakghu' ollè rèng alèrèp

13. Iyâ! Bâdâ sè ngoca' nyambhâng

14. Bâri' pandhighâ sakonni' sè noro' jâ rèng adâ sè ajhâghâ' ân

15. Mon majâng malem kèng ta' ngangghui lampu ènyamaih bhurâ'ân

16. Satèya ta' patè osom orèng alako gâdângan

17. Kadhâng nyambhâng sambi ngancèt

18. Mon ollè è jhuâl ka bhâlinan

19. Kadhâng mon ta' nyapo' pas nyellang prao laèn

20. Mon ollè sa guthung èbâng la bânnya'

21. Biasana mon kajhâmbhângan

22. Pojhur èntar prappa'en komarangan

23. Pas sajân angèn tongghârâh!!

24. Mon aèng surung mabu'kakèh

25. Ènga' satèa rèh pettengan

Pada kalimat pertama jargon bahasa Madura terletak pada kata benda yakni kata messin lari yang mengandung arti mesin yang di gunakan untuk mempercepat laju perahu, messin lari juga biasa disebut dengan messin tèmes biasany mesin in dugunakan pada saat perahu mengejar sekumpulan ikan yang sedang berlari atau sering juga digunakan untuk mengejar perahu yang lain. Selain itu, messin lari juga harganya sangat mahal sehingga pemilik perahu menggunakannya dengan hati-hati. Dari 10 informan yang saya datangi hampir semua 80 persen menggunakan istilah messin lari karena menurut mereka ungkapan yang pas untuk mengistilahkan mesin tersebut adalah messin lari karena digunakan saat perahu melaju kencang.

Sedangkan kalimat yang kedua juga termasuk dalam kata benda yakni kata jhârmudhi yang mengandung arti pekerja yang tugasnya memegang settir atau pancer, jhârmudhi sendiri adalah salah satu dari pekerja yang ikut nelayan hanya saja dia memiliki perang ganda atau memiliki tugas tambahan sebagai seorang pemegang kendali perahu. Sementara itu, apabila perahunya mendapatkan hasil tangkapan yang banyak maka jhârmudhi mendapatkan tambahan dari hasil kerja yang dilakukannya sehingga meskipun sama-sama angota nelayan hasil yang didapatkannya berbeda dengan teman-temannya yang lain.

kalimat yang ketiga adalah kata messin Jènsèt adalah sejenis mesin yang digunakan saat menghidupkan lampu, messin Jènsèt juga merukan salah satu mesin yang berada diperahu nelayan yang sangat dibutuhkan karena mesin ini memiliki peran penting apabila nelayan hendak melakukan pekerjaan dimalam hari, karena ditengah-tengah laut tidak ada listrik yang bisa memberikan cahaya bagi nelayan sehingga mesin ini sangat diperlukan.

Sementara kata pajâng pursin merupakan kata benda yang memiliki arti jala yang digunakan oleh nelayan. Banyak jenis jala yang terdapat dalam perahu serta alat digunakan untuk menangkap ikan dilaut, pajâng pursin adalah alat satu-satunya yang menjadi ciri khas atau benda yang keberadaanya tidak bisa digantikan oleh alat lain, karena dengan adanya alat ini baru bisa dikatakan bahwa ada proses nelayan. pajâng pursin ini diletakkan disamping kiri perahu nelayan untuk memudahkan pada saat dilempar kelaut untuk menangkap ikan serta pajâng pursin ini sangat rawan sekali sobek sehingga cara penggunaanya harus sangat hati-hati.

Sedangkan pada kalimat kelima terdapat kata jhâmpang yang mengandung arti talit untuk mempercepat laju jala saat ditarik, selain itu jhâmpang juga berfungsi untuk membantu meringankan beban para pekerja pada saat menarik jala jhâmpang ada dua jenis, ada jhâmpang adâ' dan ada jhâmpang budih, alat ini juga berfungsi menbantu apabila jala yang digunakan kurang pada saat menangkap ikan.

kata kerja selanjutnya terdapat pada kalimat keenam yakni kata sukle adalah sejenis lampu besar yang digunakan nelayan pada malam hari dan biasanya lampu ini sinarnya bisa sampai ke dasar laut, sukle 
juga ada dua macam (1) sukle khusus perahu yang berfungsi untuk memberikan cahaya atau menyinari perahu pada saat nelayan bekerja dimalam hari selain untuk menyinari perahu benda ini juga digunakan untuk memberi tanda kepada teman-teman nelayan yang lain, baik itu pertanda baik ataupun pertanda buruk, (1) sukle khusus ditaruh dilaut adalah lampu yang berfungsi untuk menarik ikan agar berkumpul serta digunakan sebagai pertanda bahwa derah tersebut sudah dimiliki orang lain dan ini ditaruh di messin jènsèt.

Sementara kalimat ketujuh tergolong juga dalam kata benda yakni kata ker-taker kata ini adalah sejenis benda yang digunakan nelayan pada saat menakar hasil tangkapan agar tidak ada perselisihan dalam takaran, ker-taker terbuat dari anyaman bambu yang memiliki sifat hanya bisa digunakan untuk benda padat bukan benda cair, selain sebagai tempat penakaran ini juga berfungsi sebagai tempat penyimpanan ikan apabila tempat yang tersedia tidak mencukupi.

Sedangkan kata mangghâr adalah tali yang digunakan pada saat perahu berhenti baik itu di pantai ataupun ditenganh-tengan laut, mangghâr adalah tali yang paling besar yang ada di dalam perahu serta memiliki panjang 200 meter, mangghâr berasal dari kata manggher yang dalam bahasa Indonesia dikenal dengan kata mengikat. Kata benda berikutnya terdapat pada kalimat kesembilan yakni kata sanggan tempat yang digunakan untuk berteduh serta penyimpanan barang-barang saat turun hujan, biasanya sanggan ini berada diatas perahu yang ditutupi serta bisa digunakan untuk tidur.

Kalimat berikutnya adalah kalimat yang tergolong dalam kata kerja yakni kata nyolo yang memiliki makna bahwa nelayan pergi menangkap ikan pada malam hari, biasanya mencari ikan pada tanggal $17 \mathrm{~s} / \mathrm{d}$ 08 pada saat bulan tidak ada bulan, sedangkan cara penangkapannya sangat unik yakni menggunakan lampu bangkra' yang ditinggalkan beberapa jam, semantara perahunya mencari nelayan ditempat lain, setelah itu apabia sudah ada ikan yang banyak atau berkerumun maka perahunya kembali lagi untuk menangkap ikan yang sudah ada tersebut. Lain halnya dengan kata bhurâ'ân. Bhurâ'ân berasal dari kata bhurâ yang memiliki arti têra' atau terrang, sementara dalam masyarakat nelayan bhurâ'ân memiliki makna nelayan dimalam hari hanya saja perbedaanya kalau bhurâ'ân nelayan tidak menggunakan lampu, proses pencariannyapun sangat unik yakni perahu yang mencari ikan semua lampu dimatikan dan tidak boleh ada salah satu lampupun yang hidup, dengan demikian pergerakan ikan yang ada di laut akan jelas kelihatan.

Sementara nelayan di siang hari dinamakan alèrèp, biasanya nelayan berangkat kelaut pada waktu pagi kira-kira jam 4 pagi dan pulangnya jam 6 sore, serta apabila tidak mendapatkan ikan waktu nelayan pulang lebih awal kira-kira jam 12 siang. Lain halnya dengan kata nyambhâng juga dinamakan nelayan pada siang hari, tapi perbedaanya terletak pada pemberangkatannya, kalau berangkat jam 12 siang kalau pulang jam 8 malam, serta proses pencarian ikannyapun berbeda, kalau alèrèp hampir sama dengan nyolo karena meninggalkan umpan dilaut untuk menarik ikan hanya saja tidak menggunakan lampu karena disiang hari, sementara nyambhâng mencari ikan dengan tidak menggunakan umpan, tetapi mencari langsung pergerakan ikan yang ada dilaut.

Kalimat berikutnya terdapat kata pandhighâ adalah sebutan kepada anggota nelayan, jumlah maksimal pandhighâ dalam satu perahu sebanyak 40 orang dan minimal 17 orang, sebelum pandhighâ berangkat nelayan ada yang namanya ajhâghâ' $\hat{a}$, ajhâghâ'ân adalah pekerjaan yang di lakukan oleh salah satu anggota nelayan yang bertugas memberitahukan kepada anggota yang lain kalau tiba waktunya nelayan atau berangkat bekerja.

Satèya ta' patè osom orèng alako gâdângan adalah termasuk kedalam kata kerja, karena terdapat kata gâdângan yang memiliki arti bahwa sekarang tidak banyak orang yang nelayan dimalam hari karena cuaca yang sedang buruk, kata kerja berikutnya terdapat pada kalimat ke tujuh belas yakni kadhâng nyambhâng sambi ngancèt maksud kalimat di atas adalah pekerjaan yang dilakukan oleh nelayan selain menggunakan jala besar untuk menangkap ikan mereka sesekali menggunakan waktu luangnya dangan ngancèt maksud dari kata ini adalah memancing di atas perahu pada saat nelayan siang atau biasa di sebut dengan nyambhâng.

Kata kerja selanjutnya terdapat pada kalimat ke delapan belas yakni kata bhâlinan kata ini memiliki makna pekerjaan jual beli ikan di tengah-tengah laut yang dilakukan oleh nelayan yang apabila hasil tangkapannya melebihi batas, sementara perahu yang membelinya dinamakan paroh bhâlinan. Untuk daerah Bandaran dan sekitarnya paroh bhâlinan ini adalah perahu yang datang lansung dari jawa untuk membeli ikan di laut lansung, alasannya karena kalau membeli langsung dari nelayan yang ada dilaut harganya lebir murah bahkan bisa sepuluh kali lipat lebih murah dibandingkan dipasar, selain itu ikan yang dibeli langsung dilaut akan lebih segar karena masih baru. 
Sedangkan kata nyellang adalah kata yang memiliki arti pekerjaan yang dilakukan oleh salah satu anggota nelayan apabila dia terlambat dan ditinggalkan oleh perahu yang biasanya dia ikut, dan dia ikut perahu lain.

Sementara itu, kalimat berikutnya adalah jargon bahasa Madura yang digunakan oleh masyarakat nelayan pada kata benda yakni terdapat pada kalimat ke dua puluh yakni pada kata guthung adalah tempat ikan yang digunakan pada saat hasil tangkapannya banyak, ada beberapa sebutan atau benda-benda yang digunakan oleh neyan sebagai tempat penyimpanan ikan, yang paling besar dinamakan pètak stiap perahu memiliki pètak yang jumlahnya hampir sama yakni sebanyak 10 pètak tapi yang sering digunakan sebanyak 5 buah selanjutnya baskèt alat yang digunakan untuk menyimpan ikan dan masyarakat diluar nelayan biasanya menyebut bak, rènjhing tempat ikan yang terbuat dari bambu yang ukurannya sangat besar dan biasanya digunakan apabila ikan hasil tangkapannya melebihi batas.

Selain kata benda dan kata kerja terdapat pula kata sifat yang digunakan oleh masyarakat nelayan salah satunya terdapat pada kalimat ke duapuluh satu yakni kata kajhâmbhângan memiliki arti bahwa air tenang dan pada saat itulah semua nelayan berlayar mencari ikan dilaut, lain halnya dengan kata komarangan yang memilki arti air surut, sementara tongghârâh adalah sejenis angin yang di takuti oleh seluruh nelayan karena angin ini merupakan angin yang palig besar, sehingga apabila tiba waktunya angin tongghârâh semua nelayan tidak berani keluar atau bekerja. Sementara kalimat ke duapuluh empat juga termasuk kedalam kata sifat yakni kata surung atau air pasang, serata kalimat terakhir adalah kata pettengan dimana waktunya nelayan bekerja untuk mencari nafkah di laut.

Dari hasil klasifikasi data di atas, dari sembilan puluh dua kata yang terjaring, yang tergolong dalam kata benda sebanyak lima puluh lima kata, yang tergolong kata kerja sebanyak tiga puluh lima kata, dan yang tergolong kata sifat sebanyak dua puluh dua kata. Dengan demikian dapat diberikan kesimpulan bahwa kata yang digunakan oleh masyarakat nelayan Pamekasan mayoritas menggunakan kata benda.

\section{Simpulan}

Jargon yang digunakan oleh masyarakat nelayan Pamekasan adalah jargon berbentuk kata yaitu kata benda, kata kerja, dan kata sifat. Akan tetapi penggunaan bentuk jargon yang sering digunakan adalah jargon berbentuk kata yakni kata benda sebanyak 53 kata, kata kerja sebanyak 31 kata, dan kata sifat sebanyak 34 kata.

Penggunaan jargon bahasa Madura dikalangan masyarakat nelayan Pamekasan pada tindak tutur khas. Kekhasan tindak tutur lisan jargon bahasa Madura dikalangan masyarakat nelayan Pamekasan tersebut adalah karena ternyata kata yang digunakan memiliki perbedaan "istilah" jika dibandingkan dengan masyarakat diluar nalayan di Madura padahal maksudnya sama.

\section{Ucapan Terima Kasih}

Terima kasih yang sebesar-besarnya penulis sampaikan untuk masyarakat Pamekasan atas kesediaan dan kerjasamanya selama penelitian ini dilakukan.

\section{Daftar Rujukan}

Natsir, M. Metode Penelitian. Jakarta: Ghalia Pustaka, 1998.

Narbuko, Cholid. Metode Penelitian. Jakarta: Bumi Aksara, 2003.

Petada, Mansoer. Sosiolinguistik. Bandung: Angkasa, 1990.

Rani, Drs. Abdul, dkk. Analisis Wacana: Sebuah Kajian Bahasa dalam Pemakaiaannya. Malang:

Banyumedia Publishing, 2004.

Soeparno. Dasar-dasar Linguistik Umum. Yogyakarta: PT. Tiara Wacana, 2002.

Sugono, dendi. Buku Praktis Bahasa Indonesia. Jakarta: Balai Bahasa, 1997. 